\title{
Photovoltaic Module Efficiency Optimizing Techniques: A Review
}

\author{
Muhammad Ismail Jamali a, *, Ghullam Mustafa Bhutto a, Abdul Sattar Saand ${ }^{\text {a }}$, Mohsin Ali Koondhar \\ a, Muhammad Shahzad Bajwa ${ }^{\text {a }}$, Mansab Ali Lakho ${ }^{a}$, Irfan Ali Channa ${ }^{\text {, }}$, Asif Ali Lund ${ }^{\text {a }}$ \\ ${ }^{a}$ Department of Electrical Engineering, Quaid-e-Awam University of Engineering, Science and \\ Technology Nawabshah \\ ${ }^{\mathrm{b}}$ Department of Automation, Beijing University of Chemical Technology China \\ *Corresponding Author: engrismail@quest.edu.pk
}

\begin{abstract}
The solar irradiation falling on PV-module that converted into heat hence the reducing efficiency. The dust deposition decreases efficiency and resist the amount of solar radiation interacting on surface of PV-panel. The mismatch position placed of PV string can make the mutual shading between the PV-Module, Due to this reason of shading the totally efficiency of PV system falls. To overcome all mentioned problem, in this paper the review of environmental factor and their latest minimizing techniques for optimizing performance of PV-Module is discussed. This paper merely focused on the review of cooling, Cleaning and shading effect techniques.
\end{abstract}

Keywords- Cooling Technique, Cleaning Technique, shading technique

Date Received: 20-10-2020

Date Accepted: 18-01-2021

Date Published: 08-06-2021

\section{INTRODUCTION}

$\mathrm{P}$ V Technology is one of production of renewable energy the conversion system of solar irradiation into electrical power and having a big potential at current to fulfill the rising energy demand of cities. Solar Photovoltaic (PV) technology is the very broadly endorsed technology $[1,2]$. The primary to inventing the PV system was scientist Edmund Beckerle in 1839 someplace he suggested that silicon device called as photo voltaic cells could be applied to alter the sunlight directly into electricity. The photon below the initial wavelength have enough energy to breakdown the electron hole in the semiconductor that change can push the current in the circle. The 10 to $20 \%$ of solar energy is approximately converted into electrical power, whereas the rest of solar energy is reflected back or change into heat [3].

The huge amount of solar energy that falling on PV panel is wasted into thermal energy, and that heat energy produces deterioration in the output power of $\mathrm{pv}$ panel due to high temperature [4]. The rise in temperature of pv cell originates a high reduction in the voltage and a little rise in the current, consequent of that total generation is reduced of pv module [5]. The power and efficiency are strongly belonging to the types of pv cell technology. The efficiency decreases from 0.35 to 0.8 percent for every $1 \mathrm{C}$ of temperature rise in polycrystalline $\mathrm{pv}$ module [6]. Whereas the silicon crystalline pv cells efficiency falls by 0.5 percentage with rise of $1 \mathrm{C}$ Temperature $[8,9]$.
There are two cooling techniques for optimizing the performance of $\mathrm{pv}$ module, i.e. active and passive cooling techniques [7].

The pv performance is decreased due to dust. There are many techniques for removal of dust, i.e. namely Robotic cleaning, electrostatic, Hand cleaning, automatic water showering are the present techniques for removal of dust. The selection for the removal of dust techniques depends on site and size of pv plant [10]. Partial shading (PS) is known as major power loss in PV generation that can occur owing multiple causes such as building shadow, trees shadow or running clouds and have high effects on PV module output power generation [11]. The major technique to improve the PV module performance that techniques are discussed in detail i.e. cooling PV panel, cleaning latest technique and to minimizing the PS effect techniques.

\section{LITERATURE REVIEW}

New cooling techniques are reviewed to interlink with pv module to optimize the system. The author reveals that the hydrothermal technology is applied for solar panel cooling purpose to consumes heat energy $[12,13]$. A part of heat energy was dissipated through TMG units. This heat dissipation by thermoelectric generator (TMG) unit can cause the reduce in amount of linking heat flow, at the end the solar panel temperature reduces [12]. The dust falling on the surface of PV module decreases the overall performance of PV Module. By studies it is determined that in dry area the losses of power per day recorded approximately $15 \%$ and it is also projected to supply $25 \%$ of electricity from PV module of world's overall power needs [14,15]. Method for cleaning and solution are described individually in this paper. The reconfiguration approaches are mainly used for problem of PS. Mostly 
reconfiguration approaches are used for two types suppose static and dynamic. The static reconfiguration is applied for fixed topology to optimize the power output of PV 'module under several condition of PS [16-18].

\section{A. Cooling techniques}

There are two types of techniques for cooling of pv system i.e. active and passive.

\section{a. Active cooling technique}

The active heat flow techniques, an applied source of energy and added device such as motor or fans are needed to flow the cooling medium. These techniques need extra extra energy utilization and additional device, and are very operative in terms of cooling heat flow rates [19].

\section{b. Air cooling}

Air cooling systems are usually applied in different devices for the purpose of thermal management and temperature reduction. Air cooling is used in different equipment for decreasing the temperature and heat management. Air cooling is not effective as compared to water, in air cooling system needs less material and low expensive in cost. In this system the air flow by means of airflow pump or fan [20].

\section{c. Water cooling}

Force convection is used for water flow into the tubes placed at the backside of Photo voltaic panel is an additional effective way of cooling system $[21,22]$. The liquid circulation method is reduced the temperature of $20 \%$ of the module which increase the pv system efficiency about $9 \%$. There are different novel ideas tested on pv system for maintaining uniform temperature such as converging. The studied proved that using nanofluid increases up to $24.1 \%$ in electrical efficiency of pv system as compare to without cooling system. The produced power in that case employing nanofluid was $57 \%$ and $25.6 \%$ greater than with alone PV-System and pv water coolant system one to one. Furthermore, the electrical efficiency, the heat efficiency of nanofluid coolant system was found higher than water cooled one by about $100.9 \%$.

\section{d. Water showering or spraying}

Water spray is used to wash the surface of pv system due to this the heat is decreased and performance of pv module rises [23]. By using spray of liquid, it is probable to gradually clear the surface for absorbing sunlight and decreasing the operating cell temperature. The system is designed to control the heat and nozzles for water spray installed the anterior surface of module whenever the temperature is raised the system automatically response and to flow the water. The result is showing that with cooling system panel efficiency is $11.7 \%$ and without cooling system panel efficiency is $9 \%$ [24].

\section{e. Passive’ Technique}

Furthermore, for mentioned topic active techniques and passive techniques are very useful for PV cooling system project
After active comes the passive techniques, passive method is highly applied for PV Cooling plants. In this technique no need of extra mechanical device. But the major benefit of passive method is that it does not need of additional power supply to run the chilling system. This means to simple manufacturing and low preservation charges. Few most current passive techniques and their effects on the pv system characteristics is offered in the succeeding subsections [19].

\section{f. Taper structure}

The water is used for thermal management that keeping the solar cell temperature low. Capillary structure is used for providing chilling effect passively [25].

The water is applied for heat management that maintain the operating temperature of cell at low level. This water cooling provided to the system passively by applying tube shape. The using capillary force for cooling, there are three dissimilar coolant approaches with water, $\mathrm{Al}_{2} \mathrm{O}_{3}$ /water and $\mathrm{CuO}$ /water consumed. By the observation it was found that about $30 \%, 11 \%$ and $17 \%$ decreased in module temperature as compared to without cooling respectively.

\section{g. Phase modification substantial}

The inactive second method is used to resist the temperature raise of pv system this is containing phase change material for heat controlling [26, 27]. The latent heat of mixture is absorbed by the pcm the surplus thermal energy of cell, in uniform temperature in which the phase transfer happens that resist efficiency reduction due to increment in temperature. The author reveals that the PCM arrangement can decrease the pv operating temperature by greater than $30^{\circ} \mathrm{C}$ (at solar radiation of $750 \mathrm{w} / \mathrm{m}^{2}$ and air temperature about $23^{\circ} \mathrm{C}$ ).

\section{h. Hot pipes}

Hot pipes are heat exchanging device for phases and activate latent enthalpy of high phase change and are widely flowing with in several system for heat flux high cooling such as in electronic devices and fuel cells [28].

\section{B. Cleaning technique for PV-Module}

The dust accumulation is investigated over the module and shown in fig. 1. The dust deposition depends on the track, its angle, the surface irregularities part of module, the coating etc [29]. This dirt accumulation alters due to environmental parameters i.e. ambient temperature, humidity, wind velocity and local features for instance tree's leaves, Bird dropping, traffic flow and arid areas.

Several techniques are used to minimize the significance of dust, soil and sand falling such as low expensive dry dusting, removing manually, automatically and robotics system. Fig. 2 shows by what method the cleaning is classified. 


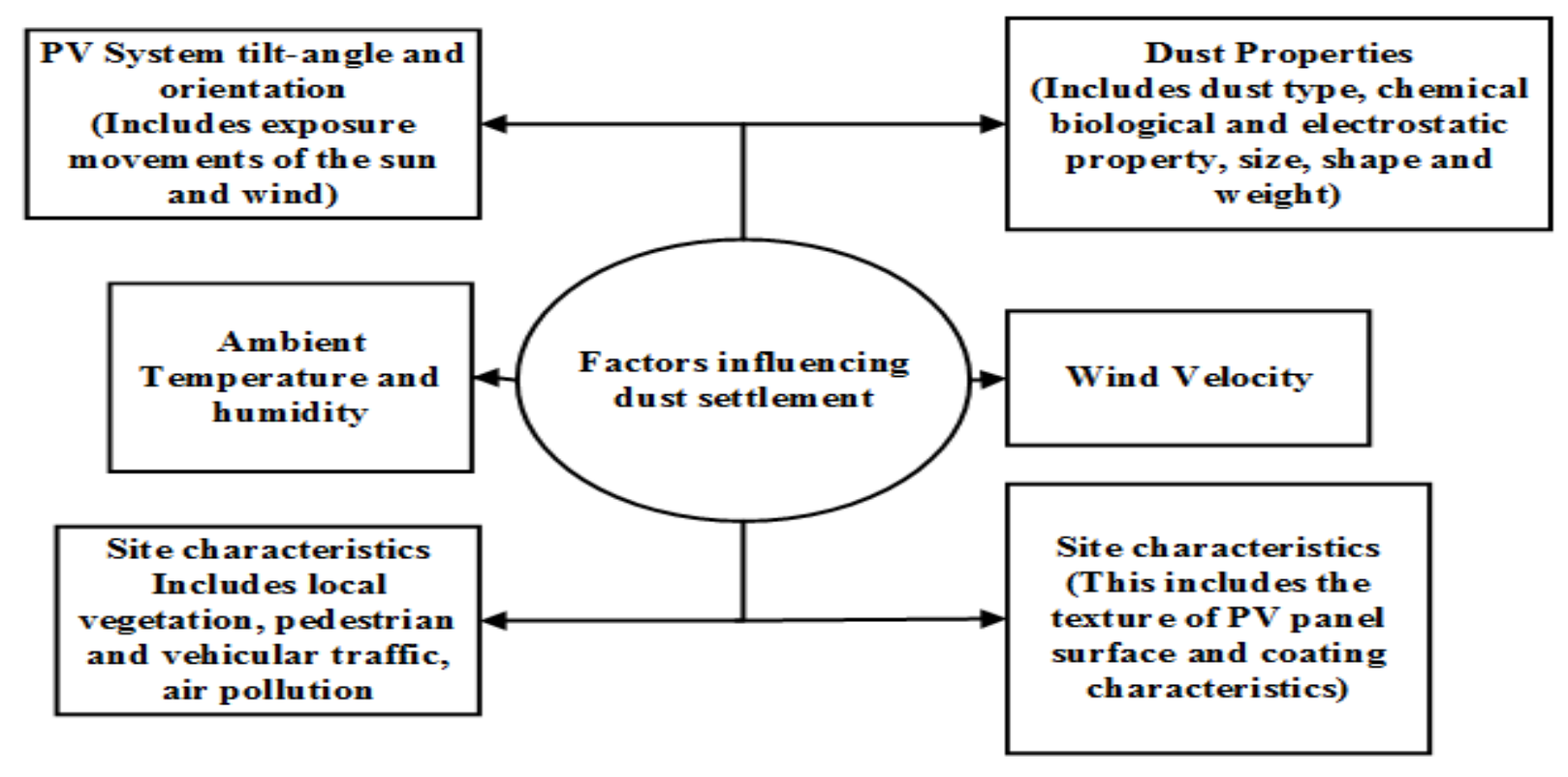

Fig. 1: Factor Effecting the Dust Accumulation [30]

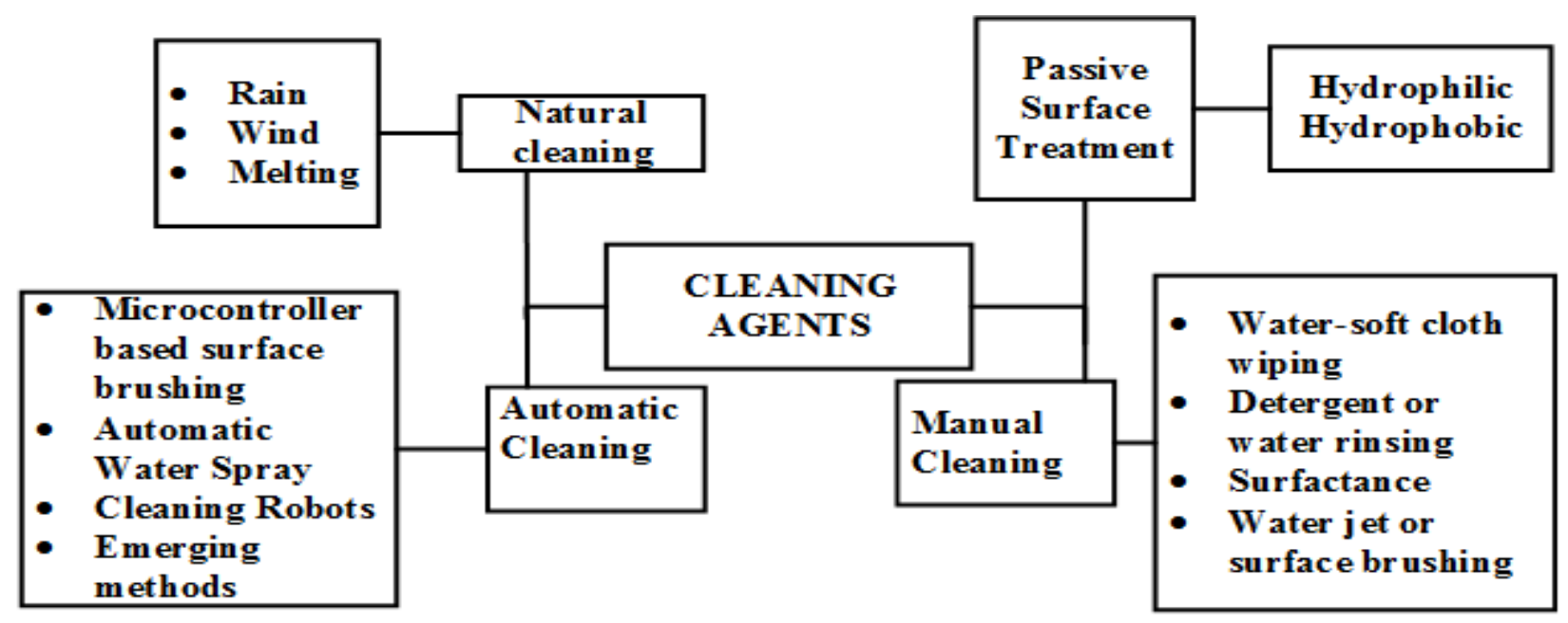

Fig. 2: Several Dusting Techniques [30]

\section{a. Enforced flow of air conditioner system}

An approach is used generally in the U.A.E and also applied in most advanced states by broadly convenience of the A.C, the conditioner throwing air by help of fan on the solar pv module for dirt elimination [31].

\section{b. Rainfall cleaning}

This the natural method for cleaning the pv module, the rain water falls remove the movable dust from PV module's surface. In this procedure the dust is left on the pv surface that is jammed on PV-module due to wetness and mostly needed high rainfall to erase the dust from panel [32].

c. Water base Erasing dust
This technique has need of huge water and continuously high pressure to erasing the dust particle matter which is stuck on the surface of PV-Module. This process needs high water in huge amount and under constant high pressure to removing the dust matter from surface. The high-pressure liquid is occasionally meet with cleaning mediators that will support arid dirt and may also be suitable for chilling the panels mounted in arid region and recompense. This procedure can be counted as necessary managing of raining dust. The draw back are many of this process such as lack of consistency when implemented in unusual region, wastage of water in large scale, probabilities of chemical accumulation on PV edges, decreased the productivity as the high pressure water system utilized substantial amount of power, hazard of blockage of water, repumping of water in 
tanks, risk of heat shockwave in the hot pv module because water is coolant than panel front and looks more dirty while pv panel is damp after erasing dust [33].

\section{d. Manual cleaning}

This procedure is similar to one who use to clean glass window, doors and high building. Dust molecule are rubbed by applying special brushes prepared with bristle to prevent any cuts. The brush and water used simultaneous rubbing and washing the panel. It is costly method that need skilled labor for daily basis cleaning [33].

\section{e. Electrodynamic screens $(E D S)$}

The solar panel is dusting by electrodynamic screen (EDS) this screen placed on pv module can grantee the automated and constant removal of dry dust deposition without use of liquid or any moving hardware parts [34]. This is known as active erasing of dirt process that consumes high potential difference to supplying the conductors (for producing electric field) of a clean screen that supports in removing the charge and upcharge dirt particle of substance from the PV Module by fluctuating them over edges of the module screen. Above 90pc of dirt is removed in a few minutes by this process that shows to be helpful in dehydrated and scorched regions [35]. A distinctive diagram of Electrodynamic system is given in Fig. 3. This process is quick than other process for removing the dust that utilized small power and using micro controller sensor (mcs).

\section{Charged dust particle}

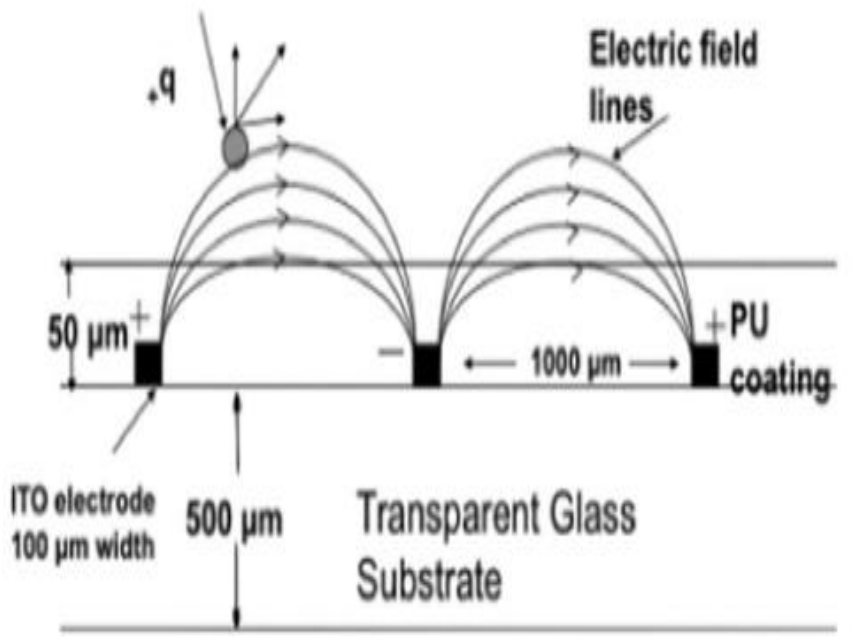

Fig. 3: Electrodynamic screen [36]

\section{f. Super hydrophobic plane (SHOP)}

SHOP or surface that can be get by applying nanofilm of titanium oxide, chemical coating and nano-patterned fabrication of glass surface.

This method can be attained by means of nanofilm of titanium oxide, organic varnishing and nano patterned assembling of glass surface. This process consumed ideal hydrophilic front screen or chemical varnishing/surface for dusting moderation. Furthermore, the advantage of SHOP, this method can chemically disrupt the organic dust by reaction of UV light [37]. Whereas, the application of TIO2 film(photocatalytic) has been designated as chemically firm and strong [38].

g. Functioning water free automatic solar PV-Module Erasing dust unit

The erasing dust device detect its present status and set the degree of module dusting as per specified data. The cleaning device control the present status and set the angle of dusting of PV module as per specified command. The erasing system contains a structure with cleaning device, and moving apparatus that select the command parallel to the panel along vertical direction

This dirt erasing system contains the setting with the dusting device and functioning the apparatus that selectively function in the sidewise direction lengthwise erasing in smooth way. The system for cleaning can be happened in all path conditional for beginning of erasing function. The further specifics for movement control by the operator given data that guides punctuation of the system's direction and range [33].

\section{Techniques for Shading Effect Mitigations}

$$
\text { a. Topology }
$$

The output power of shaded module can be optimized by using different topologies. The solar pv module can arrange in alternating topologies i.e series, parallel connection, Total cross Tied, Bridge link arrangement [39]. For bottom to top covering shadow then suitable topology is total cross tied (TCT). If shadow is bottom left side the module then series parallel connection is better to use. Any one topology can be applied if the shadow left to right of bottom. All the topology can give power same if the bottom row is fully shaded. Du su do ku arrangement local maxima can be removed and only global maxima can be kept in I.V characteristics of PV-module [40]. The author advocate that by changing the solar panel design of solar wafers in solar panel system, the PS can be mitigated [41].

\section{b. Passive Element (Bypass Diode)}

The PV output(power) is inversely proportional to the No. of shading module. pv system array is designed for connection in series and the current is same in the series connection. Let shadow present on any module that specific module can raise its resistance and reduce the voltage drop phenomena. That specific module may be in inverse bias and decrease the array current and produce hot spot state. To get rid from this phenomenon of reverse biasing and hotspot the bypass diode is used [41]. The bypass module is in reverse bias due to the No. $\mathrm{PV}$ modules in series connection.

\section{c. Active Elements:}

The PS study can be investigated by applying shading rate and amount of shading [20]. The output support vector regression(M-SVR) technique is used to estimate shading strength and optimum power point voltage of PV-Module. The Maximum power point tracking (MPPT) can be forecast from calculated data and system can be functioned with best maximum power point technique. The power loss two 
drawbacks of shading can be mitigated. The $1^{\text {st }}$ mppt is achieved the existence of Partial shading condition (PSC) and $2^{\text {nd }}$ MPPT with latest algorithm which is based on ramp alter duty cycle, these two mppt methods the world maximum power point of string is worked correctly [42].

\section{d. Adaptive PV array reconfiguration.}

Adaptive PV array reconfiguration means the connection between modules will be continuously changed to get optimistic electrical power during shading conditions.

It means that connection between panel can be instantaneously alter to achieve maximum output power during shading state. the adaptive reconfiguration is best solution to improve output power in PS state. the studies reveal that the using different technique for optimization i.e Particle swarm optimization (PSO), Scanning Algorithm, best and worth sorting algorithm (WSA), rough set theory, solar radiation equalization method, well-known subset sum problem, Ant colony optimization technique etc. the reconfiguration can be made by shifting modules from shaded area to unshaded area without changing the electrical connection of the system. the shifting of string or array can be made by using electronic switching and controllers [43].

There are several causes such as life span, soil, and PS lead to noncompliance and consequently nonuniform operating conditions. PS is a recurring phenomenon that happens when certain cells inside a module or array are sheltered by buildings, birds, running clouds. Or a few other objects, as shown in figure 4.

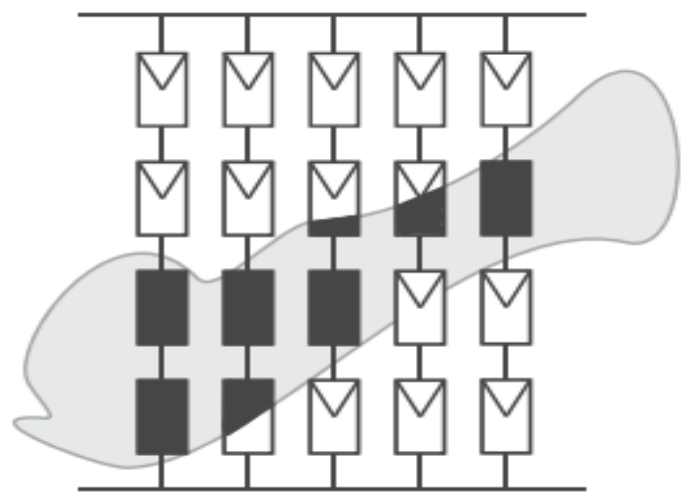

Fig 4 PV Panel under Partial Shading [44]

To improve the power output under PS states, Adaptive PV array reconfiguration can be a good solution, the researcher has reported some findings by using different optimization techniques i.e. by using Particle Swarm Optimization, scanning algorithm, Best and Worth Sorting Algorithm, Rough set theory, irradiance equalization principle, Well-known subset sum problem, Ant colony optimization technique etc. The reconfiguration can be done by shifting the modules from shade area to the un-shaded area without changing the electrical connection and another method is by shifting the shaded module from one string to another string by changing electrical connection. The position changing method is not feasible but connection changing method can be developed by using power electronics switches and controllers. The operation of these switches will be controlled by microcontroller and these microcontrollers will operate these switches as per above-said techniques. This involves high number of power electronics switches [43].

\section{CONCLUSION}

- Cooling Techniques: The major advantage of passive Colling technique is independent and no need for extra energy utilization while keeping simple assembly. In active method need extra power consumption and it is selected for highly efficient heat exchanger and improve chilling rate are required. In active' method water and air are necessary for working fluid for the coolant purpose of cell. It is observed that for environmental condition passive techniques are chilling accommodations, wind power and solar useful ac can reduce indoor temperature as much as active cooling method do. The efficiency of passive cooling system could be comparatively low. In active cooling system the forced circulation is required.

- Cleaning Technique: Few studies directed that electrostatic or electrodynamic utilized less power for cleaning the PV-Module that is effective in only dry and tilted angle front screen. There are several active and passive method are reviewed including water used dust erasing. The water-based cleaning technique, semiautomatic mechanism of dusting, labor-intensive cleaning, electro-dynamic curtain solution and so, on is discussed in this paper, it is recommended that the panel must be clean all time.

- $\quad$ Shading Techniques: The shading effect technique is discussed in this paper broadly and it is suggested that if only array of module is produced power, it is dealt with hotspot problem during shading. The bypass diode is used for the removal of hotspot. It is reported that multiple used of bypass diode can loss more power. some research paper studies about reconfiguration of module uses SP, TCT, $\mathrm{BL}$, SU DO KO pattern topology. It is also reported that shading effect is inversely proportional for power generation of $\mathrm{pv}$ module.

\section{FUTURE RECOMMENDATION}

The panel must be kept cool, Clean and to get rid from shading effects at given standard manufacturing specifics. This reviewed technique will be useful for future work.

\section{REFERENCES}

[1] A. E. Kabeel. A. E. \& M. Abdelgaied. "Performance enhancement of a photovoltaic panel with reflectors and cooling counled to a solar still with air iniection", Journal of Cleaner Production, 224, pp.40-49, 2019.

[2] P. K. Ng. \& N. Mithraratne. "Lifetime nerformance of semi-transnarent building-integrated nhotovoltaic (BIPV) glazing svstems in the tronics". Renewable and Sustainable Energy Reviews, 31, pp. 736-745, 2014. 
[3] P. Würfel. \& U. Würfel. "Phvsics of solar cells: from basic nrinciples to advanced concepts. John Wiley \& Sons", 2016.

[4] N. Kahoul. M. Houabes. \& M. Sadok. "Assessing the earlv degradation of nhotovoltaic modules nerformance in the Saharan region". Energy conversion and management, 82, pp. 320-326, 2014.

[5] M. Abdolzadeh. \& M. Ameri. "Imnroving the effectiveness of a photovoltaic water pumping svstem bv spraving water over the front of nhotovoltaic cells", Renewable energy, vol. 34, no. 1, pp. 91-96, 2009.

[6] M. Mattei. G. Notton. C. Cristofari. M. Muselli. \& P. Poggi. "Calculation of the nolvcrvstalline PV module temperature using a simple method of energv halance", Renewable energy, vol. 31, no. 4, pp. 553-567, 2006.

[7] S. Jamali. M. Yari. \& S. M. S. Mahmoudi. "Enhanced nower generation through cooling a semi-transnarent PV nower nlant with a solar chimnev". Energy Conversion and Management, 175, pp. 227-235, 2018.

[8] S. .S. Chandel. \& T. Agarwal. "Review of cooling techniaues using phase change materials for enhancing efficiencv of nhotovoltaic nower svstems". Renewable and Sustainable Energy Reviews, 73, pp. 1342-1351, 2017.

[9] M. Chandrasekar. S. Raikumar. \& D. Valavan. "A review on the thermal regulation techniaues for non integrated flat PV modules mounted on building top", Energy and Buildings, 86, pp. 692-697, 2015.

[10] N. Khadka. A. Bista. B. Adhikari. A. Shrestha. D. Bista \& B. Adhikarv. "Current Practices of Solar Photovoltaic Panel Cleaning Svstem and Future Prospects of Machine I earning Imnlementation", IEEE Access, 8, pp. 135948135962, 2020.

[11] M. Horoufianv. \& R. Ghandehari. "Ontimization of the Sudoku based reconfiguration techniaue for PV arravs nower enhancement under mutual shading conditions", Solar Energy, 159, pp. 1037-1046, 2018.

[12] A. Homadi. T. Hall \& L. Whitman. "Studv a novel hvbrid svstem for cooling solar nanels and generate nower", Applied Thermal Engineering, 179, 115503, 2020.

[13] A. Elnozahv. A. K. A. Rahman. . A. H. H. Ali. M. AbdelSalam. \& S. Ookawara. "Thermal/electrical modeling of a PV module as enhanced bv surface cooling". Journal of Clean Energy Technologies, vol. 4, no. 1, 2016.

[14] D. Deb. \& N. L. Brahmbhatt. "Review of vield increase of solar panels through soiling prevention. and a proposed water-free automated cleaning solution". Renewable and Sustainable Energy Reviews, 82, pp. 3306-3313, 2018.

[15] K. Kurokawa. K. Komoto. P. Vleuten. \& D. Faiman. "Energv from the desert. Practical nronosals for very large scale photovoltaic systems-Summary, 2006.

[16] P.R. Satnathv. R. Sharma. \& S. Dash. "An efficient SDPAR techniaue for maximum nower generation from modules of nartially shaded PV arrays", Energy, 175, pp. 182-194, 2019.

[17] Z. M. Salameh. \& F. Dagher. "The effect of electrical arrav reconfiguration on the nerformance of a PV-nowered volumetric water numn". IEEE Transactions on Energy Conversion, vol. 5, no. 4, pp. 653-658, 1990.

[18] P. R. Satnathv. \& R. Sharma. "Power loss reduction in nartiallv shaded PV arravs bv a static SDP technique", Energy, 156, pp. 569-585, 2018.

[19] A. Maleki, A. Haghighi, M. E. H. Assad, L. Mahariq, \& M. A. Nazari,

"A review on the annroaches emnloved for cooling PV cells", Solar Energy, 209, pp. 170-185, 2020.

[20] J .K. Tonui. \& Y. Trinanagnostonoulos. "Air-cooled PV/T solar collectors with low cost nerformance imnrovements", Solar energy, vol. 81, no. 4, pp. 498-511, 2007.
[21] R. Daghigh. M. H. Ruslan. \& K. Sopian. "Advances in $\begin{array}{lll}\text { liauid based nhotovoltaic/thermal (PV/T) } & \end{array}$ collectors". Renewable and Sustainable Energy Reviews, vol. 15, no. 8, pp. 4156-4170, 2011.

[22] P. Prudhvi. \& P.C. Sai. "Efficiencv imnrovement of solar PV nanels using active cooling". In $11^{\text {th }}$ IEEE International Conference on Environment and Electrical Engineering, pp. 1093-1097, 2012.

[23] M. Al-Housani. Y. Bicer. \& M. Koc. "Experimental investigations on PV cleaning of large-scale solar nower plants in desert climates: Comnarison of cleaning techniaues for drone retrofitting". Energy Conversion and Management, 185, pp. 800-815, 2019.

[24] A. Elnozahv. A. K. A. Rahman. A. H. .H Ali. M. AbdelSalam. \& S. Ookawara. "Performance of a PV module integrated with standalone building in hot arid areas as enhanced bv surface cooling and cleaning. Energy and Buildings, 88, pp. 100-109, 2015.

[25] M. Chandrasekar. S. Suresh. \& T. Senthilkumar. "Passive cooling of standalone flat PV module with cotton wick structures". Energy Conversion and Management, 71, pp. 43-50, 2013.

[26] A. Hasan. J. Sarwar. H. Alnoman. \& S. Abdelbaai. "Yearlv energv nerformance of a nhotovoltaic-nhase change material (PV-PCM) svstem in hot climate", Solar Energy, 146, pp. 417-429, 2017.

[27] J. Sarwar. A. Hasnain. A. E. Abbas. \& K. E. Kakosimos "Comparative analvsis of a novel low concentration dual nhotovoltaic/nhase change material svstem with a nonconcentrator nhotovoltaic system", Thermal Science, (00), pp. 468-468, 2019.

[28] M. H. Ahmadi. M. Ghazvini. M. Sadeghzadeh. M. Alhuvi Nazari. R. Kumar. A. Naeimi. \& T. Ming. "Solar nower technologv for electricitv generation: A critical review". Energy Science \& Engineering, vol. 6, no. 5, pp. 340-361, 2018.

[29] S. A. Marathe. \& B. P. Patil. "Mechanisms for Imnroving the Productivitv of the Existing Photovoltaic Panels: A Review". In IEEE International Conference on Comnutational Performance Evaluation, pp. 087-090, 2020.

[30] V. S. Saravanan. \& S. K. Darvekar. "Solar Photovoltaic nanels cleaning methods: A Review:, Int. J. Pure Appl. Math, 118, pp. 1-17, 2018.

[31] A. Assi. A. Hassan. M. Al-Shamisi. \& H. Heiase. "Removal of air blown dust from photovoltaic arravs using forced air flow of return air from air conditioning svstems". In IEEE International Conference on Renewable Energies for Developing Countries, pp. 1-5, 2012.

[32] A. Kimber. L. Mitchell. S. Nogradi. \& H. Wenger. "The effect of soiling on large grid-connected photovoltaic svstems in California and the southwest region of the United States". In IEEE 4th World Conference on Photovoltaic Energy Conference, vol. 2, pp. 2391-2395, 2006.

[33] D. Deb. \& N. L. Brahmbhatt. "Review of vield increase of solar nanels through soiling prevention. and a pronosed water-free automated cleaning solution". Renewable and Sustainable Energy Reviews, 82, pp. 3306-3313, 2018.

[34] M. K. Mazumder. R. Sharma. A. S. Biris. M. N. Horenstein. J. Zhang. H. Ishihara. \& O. Sadder. "Electrostatic removal of particles and its applications to self-cleaning solar nanels and solar concentrators". In Develonments in Surface Contamination and Cleaning, William Andrew Publishing, pp. 149-199, 2011.

[35] M. Mani. \& R. Pillai. "Imnact of dust on solar photovoltaic (PV) performance: Research status. challenges and recommendations". Renewahle and sustainable energy reviews, vol. 14 , no. 9 , pp. 3124-3131, 2010.

[36] W. Thongsuwan. T. Kumnika. \& P. Singiai. "Effect of high roughness on a long aging time of superhydrophilic $\mathrm{TiO} 2$ 
nanonarticle thin films". Current Applied Physics, vol. 11, no. 5, pp. 1237-1242, 2011.

[37] K. Nakata. \& A. Fuiishima. "TiO2 nhotocatalvsis: Design and applications. Journal of photochemistrv and nhotohiologv C:." Photochemistry Reviews, vol. 13, no. 3, pp. 169-189, 2012.

[38] S. Pareek. \& R. Dahiva. "Outnut nower maximization of nartiallv shaded $4 * 4$ PV field bv altering its topology", Energy Procedia, 54, pp. 116-126, 2014.

[39] B. I. Rani. G.S. Ilango. \& C. Nagamani. "Enhanced power generation from PV arrav under nartial shading conditions bv shade disnersion using Su Do Ku configuration". IEEE Transactions on sustainable energy, vol. 4 , no. 3 , pp. 594601, 2013.

[40] F. Lu. S. Guo. T. M. Walsh. \& A. G. Aberle. "Improved PV module nerformance under nartial shading conditions", Energy Procedia, 33, pp. 248-255, 2013.

[41] M. A. Ghasemi. H. M. Foroushani. \& M. Parniani. "Partial shading detection and smooth maximum nower noint tracking of PV arravs under PSC". IEEE Transactions on Power Electronics, vol. 31, no. 9, 6281-6292, 2015.

[42] V. P. Deshnande. \& S. E. Bodkhe. "Solar PV arrav reconfiguration using Ant Colonv Ontimisation for maximum power extraction under partial shading conditions". Int. Iournal of Fnoineering Research and Application, vol. 7, no. 9, pp. 21-28, 2017.

[43] Deshnande. V. P.. \& Bodkhe. S. B. (2017). Solar PV arrav reconfiguration using Ant Colonv Ontimisation for maximum nower extraction under nartial shading conditions. Int. Journal of Engineering Research and Application, 7(9), 21-28.

[44] Bidram. A.. Davoudi. A.. \& Balog. R. S. (2012). Control and circuit techniaues to mitigate nartial shading effects in nhotovoltaic arrays. IEEE Journal of Photovoltaics, 2(4), 532-546.

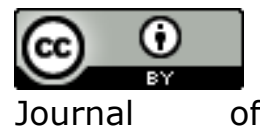

Sciences by BUITEN Commons Attribution 4.0 International License. 